\title{
BEBERAPA FAKTOR YANG BERHUBUNGAN DENGAN PERILAKU PENGGUNAAN NAPZA PADA REMAJA DI BALAI PEMULIHAN SOSIAL BANDUNG
}

\author{
Roselina Tambunan*, Junaiti Sahar**, Sutanto Priyo Hastono***
}

\begin{abstract}
Abstrak
Perilaku penggunaan NAPZA pada remaja meningkat tajam tiap tahunnya dan menimbulkan berbagai dampak kesehatan. Tujuan penelitian deskriptif korelasi dengan desain cross sectional ini adalah mengetahui hubungan faktor individu dan lingkungan dengan perilaku penggunaan NAPZA pada remaja di Balai Pemulihan Sosial Bandung. Data dikumpulkan dengan kuesioner dari 72 responden yang sedang mengikuti program rehabilitasi Therapeutic Community. Hasil penelitian menunjukkan faktor individu dengan sub variabel keingintahuan, keinginan diterima kelompok, mengikuti kecenderungan, mencari kenikmatan serta faktor lingkungan dengan sub variabel keluarga tidak harmonis dan kontrol sosial berhubungan dengan perilaku penggunaan NAPZA dengan nilai $p \leq 0,25$. Sub variabel determinan dengan perilaku NAPZA adalah keingintahuan, mencari kenikmatan, dan keluarga tidak harmonis nilai $r=0,548$ yang berarti memiliki hubungan yang kuat dan koefisien determinasi $\left(\mathrm{r}^{2}\right)$ sebesar 0,301 menjelaskan variasi variabel perilaku penggunaan NAPZA pada remaja sebesar 30,1\% sehingga dapat dikatakan ketiga variabel memiliki hasil yang cukup baik untuk menjelaskan variasi perilaku penggunaan NAPZA pada remaja. Sub variabel paling besar hubungannya dalam menentukan perilaku penggunaan NAPZA pada remaja adalah variabel keluarga tidak harmonis dengan nilai B 1,272. Keluarga dan remaja menjadi fokus intervensi dalam pencegahan perilaku penggunaan NAPZA pada remaja melalui pemberdayaan keluarga, promosi kesehatan, dan pencegahan masalah kesehatan.
\end{abstract}

Kata kunci: faktor individu, faktor lingkungan, penggunaan NAPZA

\begin{abstract}
Drug abuse case in adolescent is significantly increased every year. This study was aimed to find the relationship between individual and environmental factor with the drug abuse in adolescent at a Social Rehabilitation Center in Bandung. This correlative-descriptive research was conducted on a cross sectional design involving 72 responders who were joining the Therapeutic Community program. The data was collected through a questionnaire. This study indicated that the individual factors with the sub variables curiosity, group acceptance, following trend, getting pleasure and the environmental factors including non-harmonic family and social control were related to the use behavior of NAPZA with the $p$ value $\leq 0,25$. The determinant sub variable of drug abuse which were curiosity, getting pleasure, and non-harmonic family showed strong relationship with the $r$-value $0,548\left(r^{2}=0,301\right)$. Non-harmonic family had the highest $B$ value $(1,272)$ which also showed the closest relationship with the drug abuse behavior in adolescent. Family and adolescent are the focus of intervention to prevent the drug abuse behavior in adolescent by a preventive and health promotive actions.
\end{abstract}

Key words: drug abuse, environmental factor, individual factor

\section{LATAR BELAKANG}

Perkembangan modernisasi, arus informasi, dan komunikasi yang begitu pesat berdampak terhadap penggunaan obat-obatan terlarang di masyarakat. United Nations Office for Drugs and Crimes/UNODOC (2005) melaporkan bahwa 200 juta atau 5\% penduduk dunia menjadi penyalahguna narkotika, psikotropika, zat adiktif narkotika, psikotropika, zat adiktif (NAPZA). Sekitar tiga juta remaja menjadi penyalahguna NAPZA di Indonesia (Hidayat, 2000). Pengguna NAPZA pada tahun 2004 sekitar 40\% berusia remaja (Badan Narkotika Nasional/BNN, 2006). 
Remaja menjadi penyalahguna NAPZA dimulai dengan penggunaan NAPZA yang seolah legal di masyarakat yaitu merokok. Penggunaan kemudian bertahap mencoba minum alkohol, mariyuana, dan ke tingkat yang lebih berat seperti ecstasy, heroin, dan shabu-shabu (Catio, 2006).

BNN (2005) mengungkapkan bahwa penyalahgunaan NAPZA terkait dengan tiga faktor. Faktor tersebut yaitu: (1) faktor lingkungan yang mencakup hubungan tidak harmonis dengan orang tua, lingkungan rawan NAPZA, kurang kontrol sosial, dan tekanan kelompok sebaya; (2) faktor individu yang mencakup keinginan cobacoba, ingin diterima, ikut tren, cari kenikmatan sesaat, cari perhatian, dan ikut tokoh idola; (3) faktor zat yang mencakup ketergantungan fisik dan psikis, mudah didapat, dan relatif murah. Faktor individu dan lingkungan menjadi predisposisi terjadinya perilaku NAPZA pada remaja.

Remaja menjadi penyalahguna NAPZA sangat terkait dengan tahap perkembangannya. Remaja mengalami perubahan fisik, emosi, intelektual, dan sosial. Fase transisi dari masạ kanak-kanak ke masa dewasa disebut fase krisis dalam pembentukan identitas diri. Fase ini menimbulkan berbagai permasalahan kompleks sehingga remaja menjadi kelompok yang berisiko menyalahgunakan NAPZA (Soekanto, 1990).

Jawa Barat merupakan salah satu propinsi dengan jumlah perokok tertinggi di Indonesia, yaitu 35\%, dibandingkan Lampung 33\% dan NTB 32\% (Bali Post, 2003). Polisi daerah Bandung (2004) menjelaskan dari 2.229.750 jiwa penduduk kota Bandung, sejumlah 1.382.700 atau $62.01 \%$ pada rentang usia 15-49 tahun yang berisiko tinggi menjadi penyalahguna NAPZA. Data kepolisian Republik Indonesia (2004) menunjukkan kasus peredaran gelap dan penyalahgunaan NAPZA di Jawa Barat tahun 2002 ada dalam peringkat ke-2 yang ditangani oleh Departemen Sosial dan Lembaga Pemasyarakatan. Penelitian ini bertujuan mengetahui hubungan faktor individu dan lingkungan terhadap perilaku penggunaan NAPZA pada remaja di Balai Pemulihan Sosial Bandung.

\section{METODE PENELITIAN}

Penelitian ini dilakukan dengan metode deskriptifkolerasi dan pendekatan cross sectional. Penarikan sampel dalam penelitian ini dilakukan secara total sampel sejumlah 72 orang, yang memiliki kriteria yaitu remaja berusia antara 13-21 tahun, remaja penyalahguna NAPZA yang mengikuti mengikuti program rehabilitasi Therapeutic Community di Balai Pemulihan Sosial Bandung pada bulan April 2007. Kriteria usia remaja yang digunakan ialah menurut Bobak (1995) yaitu: remaja awal (usia10-14 tahun); remaja tengah (usia 15-17); dan remaja akhir (usia 18-21 tahun).

Variabel dependen adalah perilaku penggunaan NAPZA dan variabel independen adalah faktor individu dan faktor lingkungan. Alat ukur yang digunakan untuk memperoleh data yang dibutuhkan dalam penelitian ini adalah dengan menggunakan kuisioner. Uji validitas dan reliabilitas dilakukan pada 30 remaja yang mengikuti rehabilitasi di dua tempat rehabilitasi yang berbeda dengan tempat penelitian. Uji validitas menggunakan teknik korelasi Pearson Product Moment ( $r$ ) pada df 28 (df-2=30-2) pada taraf signifikan $5 \%$ yaitu 0,361 . Uji reliabilitas instrumen penelitian ini menggunakan Alpha Cronbach dengan interpretasi instrumen reliabel jika nilai Alpha Cronbach $>0,7$. Sebagai pengumpul data faktor individu sebanyak 45 pernyataan terkait: keingintahuan, keinginan diterima, mengikuti kecenderungan, mencari kenikmatan, mencari perhatian, meniru idola. Data faktor lingkungan sebanyak 45 pernyataan yang terkait dengan hubungan keluarga tidak harmonis, hubungan interpersonal yang buruk, orang tua menggunakan NAPZA dalam mengatasi masalah, masyarakat menggunakan NAPZA, kurang kontrol sosial, dan tekanan kelompok sebaya.

\section{HASIL PENELITIAN}

Hasil uji statistik menunjukkan ada hubungan yang signifikan antara keingintahuan, keinginan 


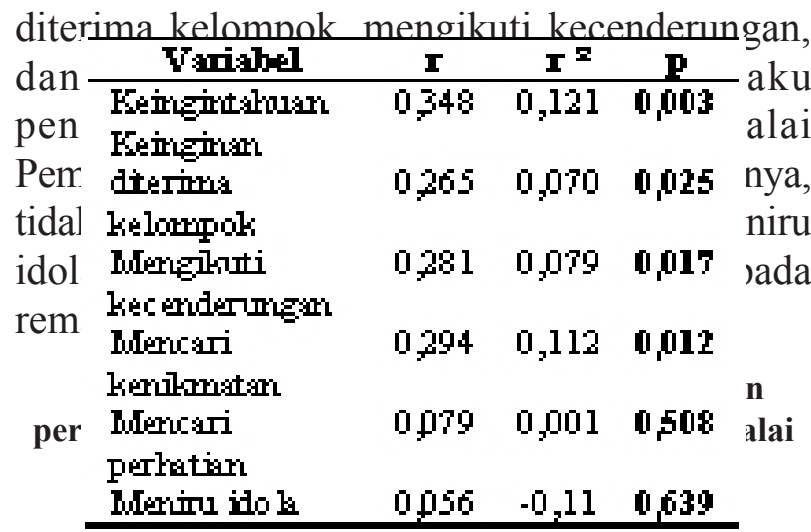

\begin{tabular}{|c|c|c|c|}
\hline vanabel & $\bar{I}$ & $I^{2}$ & $\bar{p}$ \\
\hline $\begin{array}{l}\text { Keharga tidak } \\
\text { hammonis. }\end{array}$ & 0,354 & 0,125 & 0,011 \\
\hline $\begin{array}{l}\text { Interpersonal buruk. } \\
\text { Kehurga/megota }\end{array}$ & $\begin{array}{l}0,122 \\
0,157\end{array}$ & $\begin{array}{l}0,011 \\
0,066\end{array}$ & $\begin{array}{l}0,306 \\
0,187\end{array}$ \\
\hline $\begin{array}{l}\text { kehuarga } \\
\text { mengermakan } \\
\text { HAPZA dakm } \\
\text { mengatasi masalah. }\end{array}$ & & & \\
\hline $\begin{array}{l}\text { Masyarakat kurarg } \\
\text { peduli dergan } \\
\text { pere daram dar } \\
\text { penggmaan HAPZA. }\end{array}$ & 0,206 & 0,081 & $0 \rho 82$ \\
\hline $\begin{array}{l}\text { Kurrarerya kortrol } \\
\text { sosill }\end{array}$ & 0,280 & 0,078 & 0,043 \\
\hline $\begin{array}{l}\text { Tekaranke bmpok } \\
\text { sebara. }\end{array}$ & 0,122 & 0,011 & 0,309 \\
\hline
\end{tabular}

Uji korelasi Rank Spearman digunakan untuk mengetahui hubungan sub variabel mencari kenikmatan memiliki hubungan yang sedang $(r>0,25)$. Hasil uji statistik menunjukkan ada hubungan yang signifikan antara mencari kenikmatan dengan perilaku penggunaan NAPZA pada remaja di Balai Pemulihan Sosial Bandung $(\mathrm{p} \leq 0,05)$. Hasil uji statistik menunjukkan tidak ada hubungan yang signifikan antara mencari perhatian dengan perilaku penggunaan NAPZA pada remaja di Balai Pemulihan Sosial Bandung.

Uji korelasi Rank Spearman pada sub variabel keluarga tidak harmonis dan kurangnya kontrol sosial memiliki hubungan yang sedang $(\mathrm{r} \geq 0,25)$ dan berpola positif terhadap perilaku penggunaan NAPZA pada remaja di Balai Pemulihan Sosial Bandung. Ini berarti semakin tinggi skor keluarga tidak harmonis dan kurangnya kontrol sosial maka perilaku penggunaan NAPZA pada remaja semakin tinggi.

Hasil uji statistik menunjukkan ada hubungan yang signifikan antara variabel keluarga tidak harmonis dan kurangnya kontrol sosial ( $\mathrm{p} \leq$
Hasil analisis hubungan secara bersamasama dengan $r$ sebesar 0,548 menunjukkan hubungan kuat antara perilaku penggunaan NAPZA pada remaja di Balai Pemulihan Sosial Bandung. Hasil $\mathrm{r}^{2}=0,301$ artinya $30,1 \%$ perilaku responden dapat dijelaskan oleh variasi dari ke enam variabel independen, 69,9\% sisanya dijelaskan oleh faktor lain. Pada uji $\mathrm{F}$ didapat $\mathrm{F}$ hitung $=9,402$ dengan tingkat signifikan 0,000 cocok (fitted) dengan data yang ada pada tingkat kemaknaan 5\% keingintahuan, mencari kenikmatan, dan keluarga tidak harmonis secara signifikan dapat digunakan memprediksi perilaku penggunaan NAPZA pada responden. Besar hubungan variabel bebas dengan variabel perilaku penggunaan NAPZA pada remaja dapat dilihat dari koefisien Beta.

Ketiga sub variabel bebas yang memiliki hubungan yang paling besar adalah: (1) keingintahuan 0,291, (2) mencari kenikmatan 0,228, dan (3) 


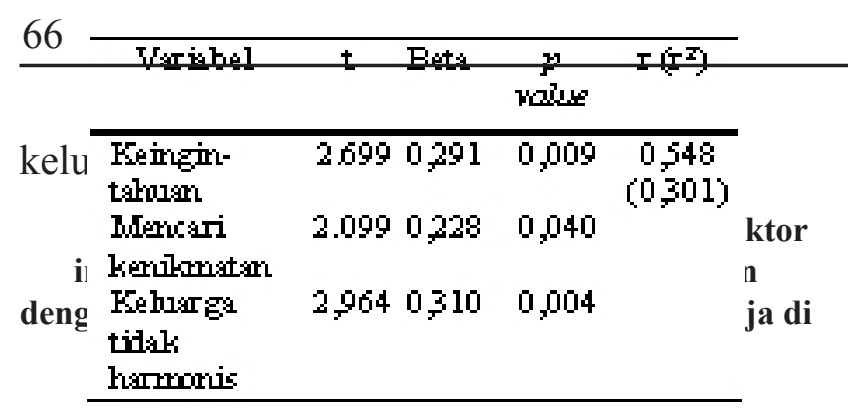

Hasil analisis multivariat didapatkan variabel determinan terhadap perilaku penggunaan NAPZA pada remaja adalah sub variabel keingintahuan, mencari kenikmatan, dan keluarga tidak harmonis. Nilai $r=0,548$ artinya ketiga variabel determinan ini memiliki hubungan yang kuat dengan perilaku penggunaan NAPZA. Variabel yang paling besar hubungannya dalam menentukan perilaku penggunaan NAPZA pada remaja adalah variabel keluarga tidak harmonis dengan nilai B 1,272.

\section{PEMBAHASAN}

Ciri remaja yaitu ingin tahu, ingin mencoba, dan cenderung melawan otoritas dalam rangka mencari identitas diri merupakan hal-hal yang menyebabkan remaja menggunakan NAPZA (Martono \& Joewana, 2006). Fase perkembangan remaja yang penuh keingintahuan membuat remaja terdorong mencoba sesuatu yang baru atau yang ditawarkan lingkungannya. Hurlock (2000) juga mengatakan masa ini adalah masa remaja memusatkan dirinya pada perilaku yang dihubungkan dengan status dewasa, yaitu merokok, menggunakan minuman keras, obatobatan, dan terlibat dalam perbuatan seks. Remaja menganggap hal ini memberikan citra hebat dan bisa seperti yang lain.

Besarnya peranan kelompok dalam kehidupan sosial remaja mendorong remaja untuk membentuk kelompok usia sebaya (Soetjiningsih, 2004).
Kelompok sebaya merupakan hal penting bagi remaja dalam fase perkembangannya, sehingga hal ini semakin berarti apabila dikaitkan dengan kebutuhan remaja akan aktifitas yang ada dalam kelompok. Respon remaja dalam menanggapi keinginan diterima kelompok dipengaruhi oleh kepercayaan, emosi, dan kecenderungan remaja dalam bersikap. Hal ini tidak lepas dari bagaimana remaja mengembangkan sikap dalam menanggapi respon dari kelompoknya.

Penggunaan NAPZA merupakan tanggapan akan pengaruh sosial. Media massa menggambarkan kebutuhan orang merasa 'high' sebagai bagian gaya hidup (Martono \& Joewana, 2006). Tingkah laku kaum remaja sangat ditentukan peer group atau teman sebayanya. Kecenderungan yang dianggap suatu kebutuhan membuat remaja tidak ketinggalan dari teman, kelompok atau masyarakat sekitarnya. Kecenderungan itu sering dianggap sebagai hal yang harus diikuti sekalipun itu berdampak buruk agar tidak dianggap ketinggalan jaman. Bagi remaja hal ini semakin dipicu dengan kebutuhan untuk mengatasi masalah.

Remaja dalam perkembangan identitas di mana seseorang kehilangan arah, tidak melakukan eksplorasi dan komitmen terhadap peran-peran tertentu akan mudah menghindari persoalan dan cenderung mencari pemuasan dengan segera sebagaimana diungkapkan Erikson (dalam Soetjiningsih, 2004). NAPZA dapat mengatasi keadaan cemas, gelisah, ketegangan, merasa kuat dan percaya diri, mengurangi rasa nyeri dan mampu mengatasi kehidupan seharihari (Soetjiningsih, 2004). Penyalahgunaan NAPZA membuat produksi neurotransmitter alami tubuh berhenti/terganggu sehingga tubuh menuntut asupan NAPZA dari luar atau menjadi ketergantungan yang terus menerus jika tidak akan mengalami gejala putus zat sesuai dengan jenis yang dipakainya (Martono \& Joewana, 2006).

Perilaku mencari perhatian tidak berhubungan dengan perilaku penggunaan NAPZA pada remaja. Kemungkinan hal ini tidak lepas dari responden penelitian yang sebagian besar adalah 
remaja akhir usia 18-21 tahun (69,4\%). Pada usia remaja akhir mencari perhatian keluarga bukan prioritas yang mempengaruhi remaja dalam berperilaku. Perilaku NAPZA pada remaja akhir lebih kepada citra diri yang mereka inginkan. Hal ini sesuai dengan pernyataan Hurlock (2000) yang juga mengungkapkan bahwa kekuatan keluarga semakin berkurang dalam perhatiannya, remaja memperoleh kebebasan secara emosional dari orang tua dan orang dewasa lain.

Lingkungan keluarga yang tidak harmonis dan konflik pada masyarakat dapat berpengaruh negatif pada remaja karena menyebabkan remaja kehilangan role model dari lingkungan/ masyarakat (Sindelar \& Fielin, 2001, dalam McMurray, 1994). Ketidakharmonisan dalam lingkungan keluarga menjadi pendorong remaja menggunakan NAPZA. Perawat komunitas dapat menjalankan pelayanan di masyarakat melalui pemberdayaan keluarga dengan meningkatkan hubungan keluarga yang harmonis melalui konsultasi permasalahan dalam keluarga yang menyebabkan ketidakharmonisan dalam keluarga.

Hubungan interpersonal dalam keluarga bagi remaja bukan suatu prioritas mengingat remaja sudah lebih luas dalam mengeksplorasi dirinya. Soetjiningsih (2004) mengatakan hubungan dalam keluarga sudah membentuk perilaku jauh sebelum usia remaja sehingga dapat dipikirkan selain hubungan interpersonal yang baik dibutuhkan dukungan lain bagi remaja untuk terhindar dari perilaku penggunaan NAPZA, seperti perilaku orang tua dan anggota keluarga dalam menyikapi penggunaan NAPZA.

Hasil penelitian ini sekalipun tidak menunjukkan hubungan antara orangtua atau anggota keluarga yang menggunakan NAPZA dalam mengatasi masalah dengan perilaku penggunaan NAPZA pada remaja, dapat dijelaskan bahwa penyalahguna NAPZA bisa menunjukkan perilaku manipulasi pada orangtua/ keluarga yang menggunakan NAPZA. Berbagai berita di media massa menayangkan bahwa banyak orang tua, pejabat atau public figure yang menjadi penyalahguna NAPZA yang tidak disadari oleh keluarga atau anggota keluarganya (SADAR, 2006).

Lembaga kontrol sosial tidak berfungsi secara maksimal akan mengakibatkan terputusnya ikatan sosial masyarakat yang menyebabkan anggota masyarakat melakukan perilaku menyimpang (Suyatno, 2006). Perilaku remaja sebagai anggota masyarakat tidak lepas dari kekuatan kontrol sosial yang ada dan dijalankan di masyarakat. Bagi remaja penyalahguna NAPZA kontrol sosial yang kurang memberi peluang untuk berperilaku lebih buruk termasuk untuk penyalahgunaan NAPZA. Oleh karena itu, sangat penting menegakkan disiplin yang dimulai di lingkungan keluarga dan masyarakat berupa aturan formal dan informal. Aturan yang tidak tegas dapat mempengaruhi perilaku remaja di sekolah dan hal ini juga mencerminkan kurang kepedulian para pengambil kebijakan dalam organisasi pendidikan ataupun institusi formal dalam penegakan disiplin atau aturan terhadap penyalahgunaan NAPZA.

Usia responden dalam penelitian ini lebih banyak usia remaja akhir, sehingga tekanan kelompok sebaya tidak berhubungan dengan penggunaan NAPZA. Walaupun hasil penelitian ini tidak mendukung, perlu dipertimbangkan tekanan kelompok sebaya sebagai pemicu bagi remaja dalam penyalahgunaan NAPZA atau sebaliknya sebagaimana hasil penelitian Hawari (1990). Penelitian tersebut menunjukkan pengaruh teman sebaya mempunyai peran $81,3 \%$ terlibatnya seseorang dalam penyalahgunaan NAPZA. Tekanan kelompok sebaya dapat menjadi stimulasi bagi remaja dalam perilaku penggunaan NAPZA.

Keingintahuan remaja sering membuat remaja mengabaikan masalah atau risiko yang berdampak dari keingintahuan pada sesuatu. Dampak yang sering diabaikan remaja dapat berpengaruh terhadap masa depan baik menyangkut biopsikososial maupun 
spiritualnya. Hal ini sesuai dengan penjelasan dari BNN (2003) bahwa masa remaja adalah masa penuh keingintahuan, mudah terpengaruh tampa memikirkan akibat di masa datang, termasuk dampak ketergantungan yang diakibatkan penggunaan NAPZA. Penyalahguna NAPZA memiliki ketergantungan untuk secara terus menerus menggunakan NAPZA. Ketergantungan ini merupakan semacam pembelajaran pada pusat kenikmatan di otak. Saat mengkonsumsi NAPZA otak memberi tanggapan mengeluarkan neurotransmitter dopamin yang memberikan kesan menyenangkan (Martono \& Joewana, 2006).

Kondisi ini akan semakin diperburuk dengan kondisi ketidakharmonisan dalam rumah tangga yang dalam penelitian ini merupakan sub variabel paling besar hubungannya dalam menentukan perilaku penggunaan NAPZA pada remaja. Lingkungan keluarga yang tidak harmonis dan konflik pada masyarakat dapat berpengaruh negatif pada remaja sehingga remaja kehilangan role model dari lingkungan (Sindelar \& Fielin, 2001, dalam McMurray, 2003).

\section{KESIMPULAN}

Ada hubungan antara faktor individu: keingintahuan, keinginan diterima kelompok, mengikuti kecenderungan, mencari kenikmatan serta faktor lingkungan: keluarga tidak harmonis dan kontrol sosial terhadap perilaku penggunaan NAPZA pada remaja di Balai Pemulihan Sosial di Bandung. Faktor determinan adalah keingintahuan, mencari kenikmatan, dan ketidakharmonisan keluarga. Variabel yang paling besar hubungannya dengan perilaku penggunaan NAPZA adalah ketidakharmonisan keluarga. Hal ini menunjukkan fokus pelayanan keperawatan adalah pemberdayaan keluarga, promosi dan pencegahan kesehatan dalam pencegahan dan penanganan perilaku penggunaan NAPZA pada remaja, baik melalui lintas program dan lintas sektor.

Peneliti menyarankan perlunya institusi pendidikan, perawat komunitas dan termasuk tempat rehabilitasi secara rutin melaksanakan pendidikan kesehatan terkait pencegahan dan penanganan perilaku penggunaan NAPZA. Aturan dan hukum yang tegas terhadap penyalahgunaan NAPZA perlu diberlakukan. Pemerintah hendaknya mengambil sikap serta menetapkan aturan yang tegas agar para remaja dapat terbebas dari penggunaan NAPZA (RU, SW).

* Staf Akademik Keperawatan Komunitas PSIK STIK Immanuel Bandung

** Staf Akademik Keperawatan Komunitas FIK UI

*** Staf Akademik FKM UI

\section{KEPUSTAKAAN}

Badan Narkotika Nasional. (2004). Komunikasi penyuluhan pencegahan penyalahgunaan narkoba. Jakarta: BNN.

Badan Narkotika Nasional. (2006). Peran remaja dalam mengatasi masalah penyalahgunaan narkoba: Mewujudkan Indonesia bebas dari ancaman narkoba 2015. Jakarta: BNN.

Bali Post. (2005). Bisakah remaja berhenti merokok.http://www.balipost.co.id.diperoleh 4 April 2007.

Bobak, M. (1995). Buku ajar keperawatan maternitas, alih bahasa, Maria. A Wijayarini, dkk. (2005). Jakarta: EGC.

Catio, M. (2006). Pencegahan dan penanggulangan penyalahgunaan narkoba. Jakarta: BNN.

Hawari, D. (1990). Al-Quran: Ilmu kedokteran jiwa dan kesehatan jiwa. Jakarta: Dana Bhakti Prima Yasa.

Hidayat, T. (2000). Penyakit akibat penyalahgunaan narkoba. Disampaikan dalam simposium di Bandung tanggal 26 Agustus 2000 . 
Hurlock, E. B. (2000). Psikologi perkembangan: Suatu pendekatan sepanjang rentang kehidupan. Jakarta: Airlangga University Press.

Martono, L.H. \& Joewana, S. (2006, April). Masa remaja cenderung rawan menggunakan narkoba. SADAR Aware \& Care, Majalah Bulanan Narkotika Nasional, 06, 20.

McMurray, D.M., Prokhorov, A.V. \& Harty, K.C. (1994). Effects of a statewide antismoking campaign on mass-media messages and smoking beliefs. Prev Med. 23 (1) 54-60.

Polda Jawa Barat. (2004). NAPZA dan penyalahgunaan pada remaja. Disampaikan pada kegiatan program kesehatan jiwa masyarakat di SMU Pahlawan Toha Bandung tanggal 23 Februari 2005.

SADAR. (2006, April ). Efek narkoba pada wanita lebih besar: Info terkini. Aware \& Care, Jurnal Resmi Badan Narkotika
Nasional, 08, 22.

Soekanto, S. (1990). Sosiologi: Suatu pengantar. Jakarta: Raja Grafindo Persada.

Soetjingsih. (2000). Tumbuh kembang anak. Jakarta: EGC.

United Nation Office for Drug Control and Crime Prevention (UNODOC). (2002). Global Illicit Drug Trends 2002.

"Siapa pun yang pernah terlibat serius dalam karya ilmiah apa pun, pasti tahu bahwa dibagian gerbang kuil ilmu pengetahuan tertulis kata-kata: Engkau Harus Punya Keyakinan."

(Max Planck)

"Keyakinan adalah penentu pengalaman seseorang. Tidak ada penyebab eksternal lainnya."

(David Hawkins)

“Keyakinan merupakan satu-satunya penawar kegagalan yang diketahui orang."

(Napoleon Hill) 